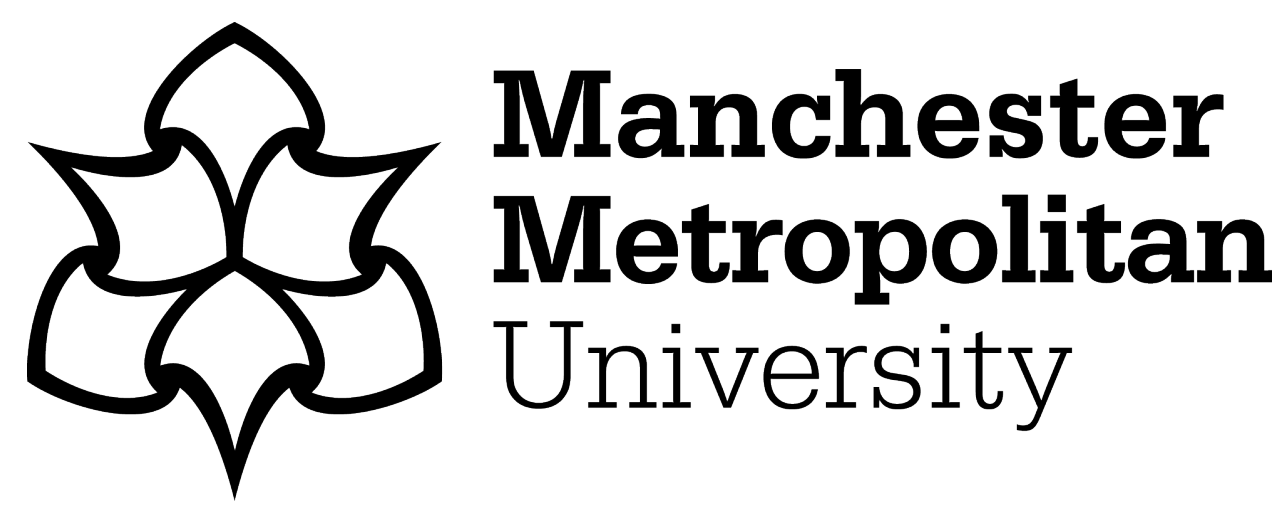

Javed, Sammar ORCID logoORCID: https://orcid.org/0000-0002-3000-936X, Syed, Jawad and Turner, Royce (2018) Gender, employment and careers in Pakistan. In: Research handbook of diversity and careers. Edward Elgar Publishing Limited, pp. 324-340. ISBN 9781785365591

Downloaded from: https://e-space.mmu.ac.uk/627008/

Version: Accepted Version

Publisher: Edward Elgar Publishing Limited

DOI: https://doi.org/10.4337/9781785365607.00031

Please cite the published version 


\title{
20. Gender, employment and careers in Pakistan
}

\author{
Sammar Javed, Jawad Syed and Royce Turner
}

This chapter examines women's participation in the labour market in Pakistan, and the religio-cultural, economic and legal factors that affect their careers and act as determinants of their position in relation to economic activity. Certain key factors in this have been widely recognised for many years. There is a well-established tradition of a lack of female participation in formal, paid employment, for example. There is also a clear division in the economic sectors in which men and women are active. Alongside this, there is also a stark contrast between men and women in relation to their hierarchical position within corporate organisations. This collection of 'signature factors' poses a significant challenge to an emerging economy with a growing population and concomitantly increasing expectations. They are also important to the position of individual women themselves, and to the increasingly significant debate on the (possibly) contested concepts of women's development, autonomy and emancipation. Indeed, the Pakistani government itself recognises these 'signature factors' facing the national economy, and states that achieving significant economic and social development depends on enhancing women's economic and social position (Ministry of Planning, Development and Reform, 2014). Pakistan 2025: One Nation - One Vision, which sets out the government's plan for the nation's development over the coming decade, recognises that 'opportunities, resources and benefits between men and women are skewed' currently, and that measures are needed to address this. Indeed the document commits to ending the discrimination against women, and to providing an environment which enables their full contribution to socioeconomic growth (Ministry of Planning, Development and Reform, 2014).

\section{WOMEN'S ECONOMIC POSITION}

Pakistan, with a population of 189 million, and a gross domestic product of US\$243.6 billion (World Bank, 2016), has a significant place in 
regional and global economic activity, though the position of women within that, or at least within the formal economy, is characterised by under-representation and underutilisation. This position is not confined to the economic sphere, but is part of a wider societal subordination. The Global Gender Gap Index, a framework devised by the World Economic Forum (WEF) to capture the magnitude of gender-based disparities and to track continuing developments, examines the position of women in four key areas - economic participation and opportunity; educational attainment; health and survival; and political empowerment - and ranks Pakistan in the second-lowest position overall, at 144 out of a total of 145 countries assessed (WEF, 2015). Pakistan, scored at 0.559 (the highest possible score is 1 , meaning parity, and the lowest possible score is 0 , meaning imparity), compares unfavourably with its geographic neighbours India, which was ranked 108 and scored 0.664, and Bangladesh, which was ranked at 64 and scored 0.704. It even manages to score lower than Saudi Arabia (rank 134, score 0.605), where women face restrictions on leaving the house and on driving. In September 2017, Saudi Arabia announced that it would allow women to drive (Hubbard, 2017). However, the change will take effect in June 2018 and its operationalisation will need to be evaluated.

The position of women in Pakistan cannot be categorised simplistically, however, as representing merely a case of subjugation. It is far more complex than that. Socially, for example, being a mother, sister, wife or daughter brings inherent respect and honour. 'Ladies first' is a commonly observed social ethos, manifesting itself in the notion of 'economic freedom' (which, in a positive light, ensures that there is no economic responsibility on females; but in a less than positive light, ensures that they have no easy access to the labour market) and in the commonly accepted cultural norm of women holding authority in domestic affairs within their families.

\section{Gender Imbalance in Labour Market Participation}

There is a major gender imbalance in labour market participation in Pakistan. The difference in the population of men and women is a mere 2 per cent, but the difference in employment levels registers at a staggering 50 per cent in men's favour. A far higher proportion of the total male population, 72.2 per cent, is employed than is the proportion of the female population, at 21.86 per cent (Government of Pakistan, 2015). This imbalance is evident across all four provinces of Pakistan - Punjab, 


\section{Research handbook of diversity and careers}

Balochistan, Sindh and Khyber Pakhtunkhwa - although cultural diversities render female labour market participation lowest in Khyber Pakhtunkhwa and Sindh, but relatively higher in Punjab (Shah and Amjad, 2011). Data on male and female participation in the civilian labour force are presented in Table 20.1.

Table 20.1 Gender, labour force participation and employment

\begin{tabular}{lrrrrrr}
\hline & \multicolumn{2}{c}{ Total population } & \multicolumn{2}{c}{ Civilian labour force } & \multicolumn{2}{c}{ Employed } \\
& $\begin{array}{r}\text { Women } \\
(\%)\end{array}$ & $\begin{array}{r}\text { Men } \\
(\%)\end{array}$ & $\begin{array}{r}\text { Women } \\
(\%)\end{array}$ & $\begin{array}{r}\text { Men } \\
(\%)\end{array}$ & $\begin{array}{r}\text { Women } \\
(\%)\end{array}$ & $\begin{array}{r}\text { Men } \\
(\%)\end{array}$ \\
\hline $\begin{array}{l}\text { Pakistan (total } \\
\text { population) }\end{array}$ & 49.00 & 51.00 & 7.75 & 24.52 & 21.86 & 72.20 \\
$\begin{array}{l}\text { Khyber } \\
\text { Pakhtunkhwa }\end{array}$ & 49.63 & 50.37 & 4.90 & 20.14 & 16.50 & 75.79 \\
$\begin{array}{l}\text { Punjab } \\
\text { Sindh }\end{array}$ & 49.81 & 50.19 & 10.19 & 25.17 & 26.57 & 67.14 \\
Balochistan & 47.51 & 52.49 & 4.53 & 26.05 & 13.19 & 82.15 \\
\hline
\end{tabular}

Source: Adapted from Government of Pakistan (2015).

\section{Inhibited Career Progress}

Another key factor is that senior positions in Pakistani organisations are almost always an exclusively male preserve (Sharjeel et al., 2016). Even where there is a significant presence of women in a sector, say education, there are few in the top echelon. Morley and Crossouard (2016), for example, found an absence of women in leadership positions in higher education in South Asia including Pakistan. Table 20.2 captures some of the key data presented by the Global Gender Gap Index: far fewer women than men work at all; of those women who do work, a far larger proportion of them work part-time than do men; women are vastly under-represented in senior positions; women's pay is far less than men's. 
JOBNAME: Broadbridge PAGE: 4 SESS: 3 OUTPUT: Wed Mar 21 09:55:43 2018

Gender, employment and careers in Pakistan

Table 20.2 Gender Gap Index 2015 - Pakistan

\begin{tabular}{|c|c|c|}
\hline Gender Gap Index 2015 - Pakistan & \multicolumn{2}{|l|}{ Data } \\
\hline Rank & \multicolumn{2}{|c|}{144 Out of 145 countries } \\
\hline Score & \multicolumn{2}{|c|}{$\begin{array}{l}0.559(0.00=\text { inequality, } 1.00= \\
\text { equality })\end{array}$} \\
\hline Total Population & \multicolumn{2}{|c|}{185.13 million } \\
\hline Overall population sex ratio & \multicolumn{2}{|c|}{$1.06 \mathrm{Men} /$ Women } \\
\hline & Women & Men \\
\hline Labour force participation (\%) & 26 & 86 \\
\hline Estimated earned income (PPP US\$) & 1503 & 8000 \\
\hline Legislators, senior officials, managers (\%) & 3 & 97 \\
\hline Professional and technical workers (\%) & 22 & 78 \\
\hline \multicolumn{3}{|l|}{ Employment } \\
\hline Adult unemployment (\%) & 8.7 & 4.0 \\
\hline Part-time employment (\%) & 45.3 & 8.5 \\
\hline $\begin{array}{l}\text { Informal employment (as \% of non-agricultural } \\
\text { employment) }\end{array}$ & 9 & 91 \\
\hline $\begin{array}{l}\text { Women/men with an account at a financial } \\
\text { institution }(\%)\end{array}$ & 3 & 14 \\
\hline $\begin{array}{l}\text { Share of women in wage employment in the } \\
\text { non-agricultural sector ( } \% \text { of total non-agricultural } \\
\text { employment) }\end{array}$ & 13 & \\
\hline Share of total R\&D personnel (FTE) (\%) & 11 & 89 \\
\hline $\begin{array}{l}\text { Ability of women to rise to positions of leadership } \\
\text { (scale } 1 \text { worst to } 7 \text { best) }\end{array}$ & 3.4 & \\
\hline Firms with female top managers (\% of firms) & 6 & \\
\hline $\begin{array}{l}\text { Firms with female participation in ownership } \\
\text { (\% of firms) }\end{array}$ & 12 & \\
\hline $\begin{array}{l}\text { Wage equality for similar work (female to male } \\
\text { ratio) }\end{array}$ & 0.61 & \\
\hline
\end{tabular}

Source: Adapted from WEF (2015).

\section{Segregation into Particular Sectors}

As is the case with male workers, the largest proportion of women who work in formal, paid employment are in agriculture, employing nearly 17 per cent of the female labour force, compared to just over 25 per cent of 


\section{Research handbook of diversity and careers}

the male labour force. Overall, women represent 23 per cent of all employed persons in Pakistan; and of these, 73 per cent work in agriculture, 14 per cent in manufacturing, 6 per cent in education, and 1.4 per cent each in 'human health and social work' and 'wholesale and retail trade' (Government of Pakistan, 2015). In all business sectors in Pakistan except one, the proportion of men employed exceeds that of women, in some cases considerably. Manufacturing, for example, employs more than 12 per cent of the male labour force, but only 3.27 per cent of the female. The wholesale and retail trade, repair of motor vehicles and motorcycles sector employs more than 14 per cent of the male labour force, but only 0.32 per cent of the female. In only one sector, 'Activities of households as employers; undifferentiated goods and services - producing activities of household for own use', is the proportion of women higher than that of men. In only two other sectors is the gap between men and women relatively small: education, which has 2.41 per cent of the male labour force and 1.44 per cent of the female; and human health and social work activities, which has 0.97 per cent and 0.31 per cent, respectively. All three of these sectors - activities of households as employers; education; and human health and social work activities - require a caring or pastoral element, traditionally strongly associated with women. Ullah (2015), for example, argues that a school teaching career has long been perceived as a natural and legitimate role for women in Muslim countries, and 49 per cent of primary school teachers in Pakistan are women (ibid.). They are, however, underrepresented in leadership positions, attributed to the impact of sociocultural norms and dominant stereotypes and gender beliefs on women's personal and professional lives (Ashraf, 2013).

Women's literacy rates trail men's, at 46 and 70 per cent, respectively; yet, despite this, the gap in enrolment in secondary education (32 per cent women, 43 per cent men), is minimal (WEF, 2015). Teaching and medicine are particularly popular with women. The Pakistan Medical and Dental Council (PMDC) reports that at least 63 per cent of medical students are women. Yet many medical graduates are inevitably eventually confronted with the choice of marriage and family, or career. In the patriarchal socio-cultural environment, many women feel that their choice is curtailed despite their education and, as a consequence, only 23 per cent of registered doctors are women (Syed, 2016). In the formal sector, the largest proportion of women are employed in agriculture, a smaller proportion in manufacturing (almost certainly textiles and clothing), and a few are in teaching, medicine, health care and social work, and craft work from home. The full data are presented in Table 20.3. 
JOBNAME: Broadbridge PAGE: 6 SESS: 3 OUTPUT: Wed Mar 21 09:55:43 2018

Gender, employment and careers in Pakistan 329

Table 20.3 Gender and major industry divisions

\begin{tabular}{|c|c|c|c|}
\hline Major industry division & $\begin{array}{l}\text { Total } \\
(\%)\end{array}$ & $\begin{array}{l}\text { Women } \\
\quad(\%)\end{array}$ & $\begin{array}{l}\text { Men } \\
(\%)\end{array}$ \\
\hline Agriculture, forestry and fishing & 42.27 & 16.88 & 25.38 \\
\hline Mining and quarrying & 0.16 & & 0.16 \\
\hline Manufacturing & 15.33 & 3.27 & 12.06 \\
\hline $\begin{array}{l}\text { Electricity, gas steam and air conditioning } \\
\text { supply }\end{array}$ & 0.41 & 0.01 & 0.41 \\
\hline $\begin{array}{l}\text { Water supply, sewerage, waste management } \\
\text { and remediation activity }\end{array}$ & 0.38 & 0.01 & 0.37 \\
\hline Construction & 7.31 & 0.05 & 7.26 \\
\hline $\begin{array}{l}\text { Wholesale and retail trade, repair of motor } \\
\text { vehicles, motorcycles }\end{array}$ & 14.64 & 0.32 & 14.32 \\
\hline Transport, storage & 5.00 & 0.01 & 4.98 \\
\hline Accommodation and food services activities & 1.60 & 0.04 & 1.56 \\
\hline Information and communication & 0.41 & 0.01 & 0.40 \\
\hline Financial and insurance activities & 0.59 & 0.02 & 0.56 \\
\hline Real estate activities & 0.38 & 0.01 & 0.37 \\
\hline $\begin{array}{l}\text { Professional, scientific and technical } \\
\text { activities }\end{array}$ & 0.45 & 0.02 & 0.44 \\
\hline Administrative and support service activities & 0.50 & 0.01 & 0.49 \\
\hline $\begin{array}{l}\text { Public administration and defence } \\
\text { compulsory social security }\end{array}$ & 2.44 & 0.05 & 2.39 \\
\hline Education & 3.85 & 1.44 & 2.41 \\
\hline Human health and social work activities & 1.28 & 0.31 & 0.97 \\
\hline Arts, entertainment and recreation & 0.12 & & 0.12 \\
\hline Other services activities & 1.80 & 0.13 & 1.66 \\
\hline $\begin{array}{l}\text { Activities of households as employers; } \\
\text { undifferentiated goods and services - } \\
\text { producing activities of household for own use }\end{array}$ & 1.06 & 0.63 & 0.42 \\
\hline $\begin{array}{l}\text { Activities extraterritorial organisations and } \\
\text { bodies }\end{array}$ & 0.02 & 0.02 & 0.02 \\
\hline
\end{tabular}

Source: Adapted from Government of Pakistan (2015).

\section{Vast Informal Sector}

Alongside the formal sector, however, is a huge informal sector, on which official data is concomitantly non-existent or, where it does exist, is 


\section{Research handbook of diversity and careers}

perforce unreliable. As with its regional neighbours in South Asia, Pakistan's workforce relies mainly on the informal sector for employment (Mahbub-ul-Haq Human Development Centre, 2015). This informal sector is not regulated, and not measured in terms of its contribution to the economy overall, but its impact is such that the formal economy would not operate as efficiently and productively as it does if it was not underpinned by the informal sector, within which women are the key players. A woman's role will often include domestic and family responsibilities, as well as providing the invisible support behind numerous (usually male) family members developing their careers.

Pakistan's huge informal sector is comprised mainly of domestic workers, the majority of whom are women. Pakistan's Bureau of Statistics estimates that 74 per cent of the entire labour force is comprised of workers in the informal sector, mostly involved in domestic work. The majority of these informal workers are rural, uneducated women who migrate to urban areas to seek work and face low wages, no benefits such as medical cover or pension, and poor working conditions; while employment protection legislation, and regulations governing requirements on remuneration, maternity leave, and health and safety, are inapplicable to them (Ebrahim, 2015).

\section{DETERMINANTS OF WOMEN'S POSITION}

\section{Religio-Cultural Context}

A key to understanding women's position in Pakistan is provided by the religio-cultural context in which the whole society exists and operates. Pakistan was founded in 1947 on Islamic principles and incorporates the word 'Islamic' even in its formal title, the Islamic Republic of Pakistan. Islam is the hegemonic force which binds society, the economy and the polity. This has a particular set of implications for women and their economic and societal position. The emphasis on the traditional family and woman's primary role as a mother or wife, albeit with some freedom to engage in economic activities, is merely one aspect of this. In essence, the religio-cultural belief system permeating Pakistani society is strongly patriarchal. This manifests itself in a much lower priority being placed on women's education and employment than on men's (Ashraf, 2013). Moreover, Islamic ideology or its practice in the Pakistani context has implications relating to segregation at work and interactions between the different sexes, dress code and behavioural norms to preserve female modesty. Such religio-cultural norms have numerous implications, many 
serving as barriers to employment and educational participation, such as the expectations on women to marry and have children at a relatively early age, to devote most of their time to family and domestic activities such as cooking, child rearing, caring for their immediate and extended families and, while the home may be seen as a legitimate domain for women, workplaces - especially workplaces where there are also male workers - may not be seen as legitimate. Shirkat Gah, a nongovernmental organisation, produced a study in 2013, for example, which showed that approximately half of Pakistani women are married before 18 years of age, and 9 per cent of girls began childbearing between 15 and 19 years old (Express Tribune, 2013). These religio-cultural norms extend even to the Pakistani (and Bangladeshi) diasporas in the United Kingdom (Wigfield and Turner, 2013).

\section{Socio-Economic Factors}

As, arguably, they do everywhere, socio-economic factors have a key bearing in the determination of individual women's positional outcome. Shenoy-Packer's (2014) study of Pune, in Maharashtra (which formed part of British India's Bombay Presidency alongside a large part of Pakistan incorporating Karachi), spanning women in the formal and informal sectors, demonstrated that for women in urban areas, participation in economic activity and in education is determined by their socio-economic background. The higher the level of that background, the higher the chances for economic and educational participation. In the rural areas, Shenoy-Packer (2014) argues that a woman's economic and educational activity will be determined by the wealth of agricultural land held by her family (again, a high level of wealth will lead to increased chances of participation, demonstrating a direct equivalent with urban areas), as well as by local need for labour, and by culture. This phenomenon indicates the intersectionality of gender and class, and also shows that women's opportunities and experiences are shaped not only by their gender but also by other dimensions of their identity.

\section{Legal Framework}

The philosophy of ensuring equal opportunities for both sexes in Pakistan has its roots in its 1973 Constitution (Hussain, 2016; Raza and Murad, 2010), and is consistent with the thoughts and examples of its founders (Syed, 2008). Therefore, one key element in determining the position of women in Pakistan is - or, at least, one would imagine it to be - the legal framework that has been in place since the nation was established in 


\section{Research handbook of diversity and careers}

1947. Article 25 of Pakistan's Constitution ensures equality before the law, stating that there shall be no discrimination on the basis of sex alone; Articles 26 and 27 provide for equal access and equality of employment in the public and private sectors (Raza, 2007). There is a raft of other legislative measures in place which also purport to enhance the position of women within Pakistani society. In 1996, Pakistan ratified the United Nations Convention on the Elimination of All Forms of Discrimination against Women (CEDAW) (United Nations, 2011) and in 2000, the Pakistan government declared a Devolution of Power Plan, which incorporated giving women a 17 per cent representation quota in the Parliament of Pakistan. This was followed, in 2002, after a nationwide consultation, by the Pakistani government's National Policy for Advancement and Empowerment of Women. Parliament enacted another law in 2010, the Protection against Harassment of Women at Workplace Act; and in 2012, established a commission to improve women's status under the National Commission on the Status of Women Act 2012. The year 2016 saw a new law in Punjab, Protection of Women Against Violence, which criminalised all forms of violence against women including physical violence, abusive language, stalking and cybercrimes (News, 2016). Despite this legislative framework, there appears to be little impact on actual equal employment opportunities for women (Ali and Knox, 2008). Two key factors militate against the prospects for any meaningful change being brought about by these legislative measures: weak implementation (or, possibly, a weak desire to implement), and the vast size of the unregulated informal sector.

Ali and Kramar (2015) suspected that weak legal implementation was a widespread phenomenon across many Muslim majority countries, including Pakistan and Bangladesh, being influenced by the prevailing religious-political culture and by employers' interpretations which are largely, and unsurprisingly, imbued with particular interpretations of Islamic beliefs and values (Ali, 2013; Sidiqi, 2003). One specific example is the Minimum Wages Act of 1961, which covers domestic workers, working almost exclusively in the informal sector, where the efficacy of its implementation is strongly disputed (Ebrahim, 2015). In relation to the informal sector, it was not until 2013, when the first ever bill to enhance the rights of this legion of workers was presented to the Senate (Paycheck.pk, 2016), that any attention had even been paid to its appalling employment conditions. As with other legislation discussed above, the efficacy of its implementation is open to considerable question. Although progress has been slow, then, some legislation, particularly the Punjab Industrial Relations Act 2010, has engendered what many will see as a positive development, in that it allowed for the formation of the 
first domestic workers' union in Lahore in early 2015. Not only is the establishment of the union itself of momentous significance, but the fact that 225 of its 235 members are female domestic workers is even more so (Ebrahim, 2015; Paycheck.pk, 2016). One of the objectives of the trade union is to push for further legislation to regulate the informal sector (Ebrahim, 2015).

\section{PROGRESS FOR WOMEN}

Aside from the religio-cultural and legal influences, there are some other factors which are militating to promote female participation in economic activity: economic necessity, technological change, and a trend to delay marriages. One of principal elements that serves to promote women's employment is economic necessity. Just as with Western national economies during the post-Second World War era, economic growth requires increased labour power and this draws forth female participation. Indeed, Pakistan 2025: One Nation - One Vision recognises that Pakistan's economic growth is dependent upon increased female economic participation (Ministry of Planning, Development and Reform, 2014).

Another factor that may potentially promote increased female economic activity is technological change, especially the development of online communications and work stations, which through allowing the prospect of working at home, or even running a business from home, is enhancing the flexibility available to women facing domestic pressures. Some employers, such as Unilever Pakistan and Pakistan Telecommunications Company Limited (PTCL), have provided flexible working arrangements, in recognition of their own business interests as well as benefiting women and their employment position. Unilever Pakistan, for example, has introduced an Agile Working programme at its head office in Karachi, which enables individuals to work from outside the office during the regular workday, meaning that 'agile workers' can work from home, office or alternative locations during business hours, so long as they can be reached via telephone or email at all times (Nemat, 2010). More recently, in October 2015, PTCL (2015) introduced WorkEase: new flexible work arrangements for its employees, which includes flexible working hours, and a work from home facility for working mothers. It gives employees options on working hours, providing greater autonomy to begin and end their workday. Some employers, such as textile factories in Lahore and Faisalabad, also provide segregated working environments for women, women-only transport facilities, separate rest rooms, and 


\section{Research handbook of diversity and careers}

baby care facilities, to comply with local and Islamic traditions of female modesty and enable women's employment.

\section{INTERVENTIONS: WOMEN'S EMPOWERMENT SCHEMES}

A series of women's empowerment schemes have been introduced in Pakistan in recent times. These include initiatives by government departments, such as the Jafakash Aurat (hardworking woman) Projects launched by the Ministry of Women Development (now devolved to provincial level) developed in partnership with the private sector (UN, 2011), and similar endeavours at the provincial level. The government of Punjab province, for example, established a dedicated Women Development Department (WDD) in 2012, aimed at promoting multiple reforms in legal, administrative and institutional spheres while also providing new initiatives to safeguard women's rights, uplift their socio-economic status, and ensure that opportunities are available to them (WDD, 2016).

Some universities have launched initiatives to help support the development of women. One example is the Pakistan Women Entrepreneurship Program (PWEP) being run at the Lahore University of Management Sciences (LUMS) in collaboration with the American University (AU), with the support of the US Department of State and the US-Pakistan Women Council, which aims to enhance female entrepreneurial capacity (Bodley-Bond, 2015). In the spirit of positive action, the government has also formed women-only universities and technical colleges to promote women's education and prospective employment. Fatima Jinnah Women University (FJWU), based in Rawalpindi, which has a vision to promote and facilitate studies and research in various fields of higher education, is one such institution (FJWU, 2016).

There are also private sector initiatives such as a micro-credit scheme launched through the Khushhali Bank, the Agriculture Development Bank and the First Women Bank. The First Women Bank, with its distinct charter focusing on supporting women's specific needs in trade and the professions, provides credit facilities to businesses where a woman is the managing director, or 50 per cent of shares are held by women, or 50 per cent of the employees are women. In contrast to most Pakistani companies, the bank's board of directors has an equal gender ratio, with four women and four men directors, while the management team has eight women and four men (First Women Bank, 2012).

As well as these government and private sector initiatives, third-sector organisations are also playing a part in supporting women's economic 
and social development. The Kashf Foundation (2016), for example, which established the first specialised micro-finance programme in Pakistan in 1999 targeted specifically at women from low-income communities, provides micro-finance to female-led initiatives across Pakistan. As noted above, although interventions to boost the economic and societal positions of women in Pakistan have had only limited impact (Ali and Knox, 2008), it is argued that the Kashf Foundation's work has already been strongly beneficial to rural women in Punjab and other provinces (Raza et al., 2016). There are several other third-sector organisations operating in Pakistan that are focused on supporting working women's welfare. Notable ones include the Women Social Welfare Organization (WSO), Support with Working Solution (SWSS), the Kaarvan Foundation, the Oriental Women Organization, the Shahina Aftab Foundation, the All Pakistan Women Association, and the Women Industrial Social Education Society (WISES) (Pakistan NGOs Directory and Guide, 2013). Many are making a tangibly beneficial impact on women's lives. The Kaarvan Foundation, for example, operating in 900 villages across 11 districts, has reached more than 13000 women to provide them with training and skills development (Kaarvan, 2015). In relation to women who are self-employed, or who are seeking selfemployment, women's chambers of commerce are providing support in all Pakistan's major cities. An organisation similar to Bangladesh's Self-Employed Women's Association (2016), a trade union providing support to 'poor, self-employed women workers', has yet to be developed in Pakistan, however.

In addition to these schemes mentioned above, there are initiatives generated by international organisations and overseas governments. One such is Promoting Gender Equality for Decent Employment (GE4DE), launched in partnership by the International Labour Organization and Department of Foreign Affairs, Trade and Development Canada (DFATD). The largest project in South Asia aimed at improving gender equality at work, it aims to promote equal opportunities for women in relation to employment, enhance their skills and employability in selected districts, and strengthen media capacity to raise awareness of the issues facing women in both the formal and informal sectors of the economy (International Labour Organization, 2016).

\section{CONCLUSIONS}

The vast majority of women in Pakistan remain subordinate to men in almost all spheres of human activity. Although honoured and respected 


\section{Research handbook of diversity and careers}

for their domestic roles as wives, mothers and sisters, their position is characterised by a lack of economic participation; or, where there is participation, it is likely to be part-time, casualised, segregated to particular jobs within particular sectors such as textiles or domestic work and, moreover, is likely to be within a vast, unregulated, unmeasured 'informal' sector. Their remuneration is almost always significantly less than men's. Their chances of progressing up the career ladder are significantly less than men's.

There are, of course, some significant exceptions to this, such as Mushraf Hai, the former chief executive of Unilever Pakistan, or Roshaneh Zafar, the managing director of the Kashf Foundation, but these are individual exceptions to a general picture which, although showing some signs of change, is changing only very slowly. Some factors are working to promote female economic participation, such as new technology which allows more flexibility in terms of where, how and when women can work; and opportunities are being generated by the continued quest for economic growth which will require an increasing workforce drawn from what Marxists would call the 'reserve army of labour' which, in Pakistan's case, is women. In the contemporary context and polity, however, change to traditional patterns of economic organisation in relation to gender is not likely to take place at a gallop.

The determinants of women's position in Pakistan are not difficult to identify. Religio-cultural factors are obviously a key element. Women are freed under Islam from the need to earn money to ensure individual and familial survival; but this means, concomitantly, that they face many barriers if they do attempt to engage in economic activity: restrictions on working with men; a generalised belief that they should be restricted to particular occupations; an often-held belief that they may not be capable of, or should not be trusted with, certain jobs; and a host of other factors which are widely recognised.

Although gender equality in employment is ostensibly protected by law, even enshrined in the nation's founding Constitution, such legislation lacks impact, either because it is not implemented effectively or because how it is implemented is left to individual organisations. Interventions to support the position of women, from the federal and provincial governments of Pakistan, universities, private sector companies, third-sector organisations, and international organisations such as the United Nations' International Labour Organization, will chip away at the edifice of male domination and female subjugation, and may eventually have a wider impact as time moves on and Pakistan becomes more exposed to globalisation and technology. The extent of the potentially catalytic impact of social media, for example, remains unpredictable. 
There is no doubt, also, that these varied interventions will make a major difference to the lives of many individual women; but their sufficiency for modification of an economic structure remains to be seen.

\section{REFERENCES}

Ali, F. (2013), 'A multi-level perspective on equal employment opportunity for women in Pakistan', Equality, Diversity and Inclusion: An International Journal, 32 (3), 289-309.

Ali, F. and A. Knox (2008), 'Pakistan's commitment to equal employment opportunity for women: a toothless tiger?' International Journal of Employment Studies, 16 (1), 39-58.

Ali, F. and R. Kramar (2015), 'An exploratory study of sexual harassment in Pakistani organizations', Asia Pacific Journal of Management, 32 (1), 229-249.

Ashraf, D. (2013), 'Women teaching and leading in Pakistan: exploring the challenges and possibilities', in J. Kirk, M. Dembélé and S. Baxter (eds), More and Better Teachers for Quality Education for All, accessed 15 August 2016 at https://moreandbetterteachers. files.wordpress.com/2013/09/mbt_chapter-9.pdf.

Bodley-Bond, C. (2015), 'American university launches Pakistan women entrepreneurship program', accessed 8 August 2016 at http://www.american.edu/sis/news/20150420American-University-Launches-Pakistan-Women-Entrepreneurship-Program.cfm.

Ebrahim, Z. (2015), 'Pakistan's domestic workers long for low pay and overwork to be a thing of the past', Inter Press Service News Agency, 9 February, accessed 13 June 2016 at http://www.ipsnews.net/2015/02/pakistans-domestic-workers-long-for-low-pay-andoverwork-to-be-a-thing-of-the-past/.

Express Tribune (2013), 'Social customs: nearly half of Pakistani women are married before 18', accessed 8 August 2016 at http://tribune.com.pk/story/597697/socialcustoms-nearly-half-of-pakistani-women-are-married-before-the-age-of-18/.

Fatima Jinnah Women University (FJWU) (2016), 'Welcome to Fatima Jinnah Women University', accessed 8 August 2016 at http://www.fjwu.edu.pk.

First Women Bank (2012), 'First Women Bank Ltd', accessed 8 August 2016 at http://www.fwbl.com.pk.

Government of Pakistan (2015), Labour Force Survey 2014-15 (Annual Report), Pakistan Bureau of Statistics, accessed 8 August 2016 at http://www.pbs.gov.pk.

Hubbard, B. (2017), 'Saudi Arabia agrees to let women drive', New York Times, 26 September, accessed 9 December 2017 at https://www.nytimes.com/2017/09/26/world/ middleeast/saudi-arabia-women-drive.html.

Hussain, R. (2016), 'Pakistan', The Oxford Encyclopaedia of the Islamic World, Oxford Islamic Studies Online, accessed 8 August 2016 at ttp://www.oxfordislamicstudies.com/ article/opr/t236/e0616.

International Labour Organization (2016), 'Promoting Gender Equality for Decent Employment (GE4DE)', accessed 8 August 2016 at http://www.ilo.org/islamabad/ whatwedo/projects/WCMS_377960/lang-en/index.htm.

Kaarvan (2015), 'Our impact', Kaarvan Crafts Foundation, accessed 8 August 2016 at http://kaarvan.com/impact-2-2/.

Kashf Foundation (2016), 'What we do', Kaarvan Crafts Foundation, accessed 8 August 2016 at http://kashf.org/?page_id=16.

Mahbub-ul-Haq Human Development Centre (2015), The Human Development in South Asia 2015: The Economy and the People, Lahore: Crossmedia.

Ministry of Planning, Development and Reform (Government of Pakistan) (2014), 'Pakistan 2025: One Nation - One Vision', accessed 8 August 2016 at http://www.pc. gov.pk/wp-content/uploads/2015/05/Pakistan-Vision-2025.pdf. 
JOBNAME: Broadbridge PAGE: 15 SESS: 3 OUTPUT: Wed Mar 21 09:55:43 2018

\section{Research handbook of diversity and careers}

Morley, L. and B. Crossouard (2016), 'Women's leadership in the Asian Century: does expansion mean inclusion?', Studies in Higher Education, 41 (5), 801-814.

Nemat, M. (2010), 'Unilever tries out "agile working"', Express Tribune, 6 September, accessed 15 August 2016 at http://tribune.com.pk/story/47007/unilever-tries-out-agileworking/.

News (2016), 'Women Protection Bill becomes law in Punjab', 29 February, accessed 20 June 2016 at http://www.thenews.com.pk/latest/101796-Women-Protection-Billbecomes-law-in-Punjab.

Pakistan NGOs Directory and Guide (2013), a website providing comprehensive directory of all the major NGOs and NPOs working in Pakistan, KGM Consultants, accessed 8 August 2016 at http://www.ngo.com.pk/rights/women_welfare_ngos.htm.

Pakistan Telecommunications Company Limited (PTCL) (2015), 'PTCL implements flexible work arrangements', accessed 15 August 2016 at https://www.ptcl.com.pk/ Home/PressReleaseDetail/?ItemId=502\&linkId=130.

Paycheck.pk (2016), 'Domestic workers in Pakistan', accessed 15 August 2016 at http://www.paycheck.pk/main/labour-laws/domestic-workers-in-pakistan.

Raza, A. and H.S. Murad (2010), 'Gender gap in Pakistan: a socio-demographic analysis', International Journal of Social Economics, 37 (7), 541-557.

Raza, A., H.S. Murad and M.Z. Zakar (2016), 'Contextualizing poverty and culture: towards a social economy of community centered knowledge based development', International Journal of Social Economics, 43 (5), 486-501.

Raza, F.A. (2007), 'Reasons for the lack of women's participation in Pakistan's workforce', Journal of Middle East Women's Studies, 3 (3), 99-102.

Self-Employed Women's Association (2016), accessed 15 August 2016 at http://www. sewa.org/.

Shah, S.A.M. and S. Amjad (2011), 'Cultural diversity in Pakistan: national vs provincial', Mediterranean Journal of Social Science, 2 (2), 331-344.

Sharjeel, M.Y., H. Siddiqui and G. Khwaja (2016), 'Work-family conflict and career orientation amongst employed women in banks and hospitals', Pakistan Business Review, 17 (4), 950-964.

Shenoy-Packer, S. (2014), India's Working Women and Career Discourses: Society, Socialization and Agency, London: Lexington Books.

Sidiqi, D.M. (2003), 'The sexual harassment of industrial workers: strategies for intervention in the workplace and beyond', CPD-UNFPA working paper series no. 26, Centre for Policy Dialogue, New York City: United Nations Population Fund Publication.

Syed, J. (2008), 'Pakistani model of diversity management: rediscovering Jinnah's vision', International Journal of Sociology and Social Policy, 28 (3/4), 100-113.

Syed, R. (2016), 'DoctHERs in Pakistan empowering female doctors', Al Jazeera, 7 April, accessed 20 June 2016 at http://www.aljazeera.com/indepth/features/2016/03/doctherspakistan-empowering-female-doctors-160328143049724.html.

Ullah, H. (2015), 'School teaching as a feminine profession: the legitimization and naturalization discourses in Pakistani context', Papers from the Education Doctoral Research Conference, University of Birmingham, 28 November.

United Nations (UN) (2011), 'Committee on the Elimination of Discrimination Against Women (CEDAW), Consideration of reports submitted by States parties under Article 18 of the CEDAW: 4th periodic reports of States parties: Pakistan, 24 September', accessed 20 June 2016 at http://www.refworld.org/docid/514b009d2.html.

Wigfield, A. and R. Turner (2013), 'South Asian women and the labour market in the UK: attitudes, barriers, solutions', Journal of Community Positive Practices, 12 (4), 642-666.

Women Development Department (WDD), Government of the Punjab (2016), 'Overview', accessed 20 June 2016 at http://wdd.punjab.gov.pk/overview.

Columns Design XML Ltd / Job: Broadbridge-Research_handbook_of_diversity_and_careers / Division: 20-Chapter20forTS22 /Pg. Position: 15 / Date: 20/3 
JOBNAME: Broadbridge PAGE: 16 SESS: 3 OUTPUT: Wed Mar 21 09:55:43 2018

Gender, employment and careers in Pakistan 339

World Bank (2016), 'Pakistan', accessed 27 August 2016 at: http://data.worldbank.org/ country/pakistan.

World Economic Forum (WEF) (2015), The Global Gender Gap Report 2015, accessed 20 June 2016 at https://www.weforum.org/reports/global-gender-gap-report-2015/.

Columns Design XML Ltd / Job: Broadbridge-Research_handbook_of_diversity_and_careers / Division: 20-Chapter20forTS22 /Pg. Position: 16 / Date: 20/3 
JOBNAME: Broadbridge PAGE: 17 SESS: 3 OUTPUT: Wed Mar 21 09:55:43 2018

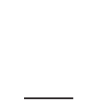

Columns Design XML Ltd / Job: Broadbridge-Research_handbook_of_diversity_and_careers / Division: 20-Chapter20forTS22 /Pg. Position: 17 / Date: 20/3 